\title{
Reagan AIDS panel disappoints health-care professionals
}

\section{Washington}

President Ronald Reagan last week announced the membership of the commission that will advise him on "a fullfledged strategy for battling AIDS (acquired immune deficiency syndrome)". The president made his announcement during a visit to the National Institutes of Health. Although Reagan referred to the formation of the commission as a "big step against AIDS", doubts immediately surfaced about the qualifications of the panel, raising questions about its effectiveness.

Reagan announced last month that $\mathrm{W}$. Eugene Mayberry, chief executive officer of the Mayo Foundation in Rochester, Minnesota, would chair the 13-member presidential commission. Since then there has been an internal debate at the White House, focusing on the question of whether a homosexual should be included. Before the president's

\section{Barry Jones bounces} back into new post

\section{Sydney}

THE reshuffle following the Australian Labor party's election victory will leave the former Minister for Science, Barry Jones, with considerable responsibility for science, despite the disappearance of his own department. In the new government he has been given a ministerial post assisting the Minister for Industry, Science and Commerce, Senator John Button.

The appointment will allow him to continue the restructuring of the Commonwealth Science and Industrial Research Organization (CSIRO) and to expand the Commission for the Future, a pet project he set up in 1984. In the Department of Industry, Technology and Commerce (DITAC), the commission may be able to take on a function similar to that of the US Office of Technology Assessment.

Other changes that have reunited responsiblity for science and technology in one ministry have been welcomed. In particular, the transfer of the Australian Nuclear Science and Energy Organisation from the Ministry of Minerals and Energy to DITAC should bring an end to territorial squabbles with CSIRO. Doubts still remain over the promised creation of the Australian Research Council. The government seems to be thinking of putting it in with the Department of Education, Employment and Training rather than DITAC even though the report that recommended its establishment argued that it should be answerable to the Minister for Science.

Charles Morgan announcement, word leaked that Frank Lilly, chairman of the genetics department at Albert Einstein Medical Center in New York would be on the panel. Lilly is homosexual.

Lilly is also the only panel member with a graduate science degree. He was a member of the National Academy of Science's com-mittee on a national strategy for AIDS (see Nature 324, 3; 1986). The other members with a health background are Woodrow Myers, health commissioner for the state of Indiana, William Walsh, founder of Project Hope, Colleen Conway-Welch, dean of nursing at Vanderbilt University, Theresa Crenshaw, a physician specializing in sexual therapy, and Burton James Lee, a

I have no personal recollection of being told about this AIDS

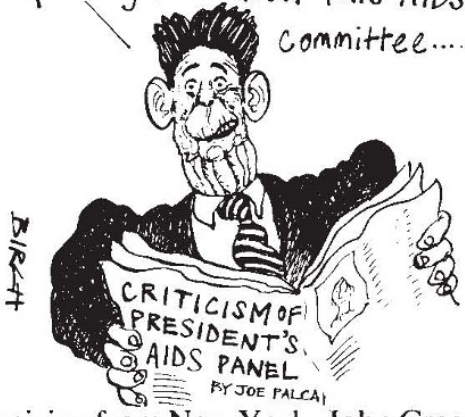

physician from New York. John Creedon, chief executive officer of Metropolitan Life Insurance Company, has also been involved in health-care financing.

The commission will make its first report to the president in 90 days, with a final report within one year. The panel's brief is comprehensive. It will make recommendations on research, treatment, ethics and international participation.

But many believe the panel is illequipped to cope with the complex questions raised by AIDS. Sheldon Wolff, co-chairman of the National Academy's committee, says he is sorely disappointed with the president's selections.

One of the recommendations of the academy's report was for an independent advisory panel on AIDS. But Paul Volberding of San Francisco General Hospital's AIDS unit - and a member of the academy panel - says the president's panel lacks the strong, well-informed, independent people who could make a difference to the way the country reponds to the AIDS problem.

Joseph Palca

Other panel members are Richard De Vos, cofounder of Amway Corporation, John Cardinal O'Connor, archbishop of New York, Penny Pullen, representative to the Illinois State House of Representatives, Cory SerVaas, editor and publisher of The Saturday Evening Post, and Admiral James Watkins, retired.

\section{Genentech loses another patent dispute in court}

\section{Washington}

Close on the heels of the British High Court decision ruling its patent for tissue plasminogen activator (TPA) invalid (see Nature 328, 189; 1987), Genentech is again the loser. A US judge ruled last week that Genentech is infringing a patent for Factor VIII:C, a natural blood-clotting agent used to treat haemophiliacs, that it is producing by recombinant means.

The patent for Factor VIII:C is held by the Scripps Clinic and Research Foundation of La Jolla, California, and covers the molecule itself and several methods for purifying it from pooled human blood plasma. Scripps licensed the patent to Rorer Group, Inc., which sued Genentech for infringement. Rorer has also sued Chiron and Baxter Travenol, both working on the recombinant factor.

The dispute is seen as the first trial case of "an isolator versus a cloner". Several of the major products being developed by biotechnology companies using recombinant DNA technology may also be isolated from blood or tissue. Although things found in nature cannot be patented, current US patent law provides protection for companies that find a way to produce a substance in a form that is "more pure" than that which occurs naturally. Factor VIII: $C$ is the active clotting portion of the Factor VIII complex found in blood, and purifying it is therefore patentable.

The purity of Factor VIII is a central issue, because the handful of current producers get their plasma from paid donation centres. Until 1985, donors were not screened for the AIDS (aquired immune deficiency syndrome) virus, even though a significant proportion of them had used intravenous drugs. As a result, according to a National Haemophilia Foundation study, two-thirds of the roughly 20,000 haemophiliacs in the United States have been infected.

Although donor-screening and heatsterilization are now routine for Factor VIII manufacturers, producing it by recombinant DNA techniques would totally remove the risk of viral infection. Accordingly, the judge did not issue a preliminary injunction to prevent Genentech from making or using recombinant Factor VIII:C, as "haemophiliacs could suffer if there is any delay in bringing recombinant [Factor VIII] to the market".

Rorer offered to license Factor VIII:C to Genentech, but Ernenst Lipscomb, Rorer's patent counsel, said Genentech told them in effect that they could go to Hell. Genentech plans to appeal against the decision. 